\title{
IMPLEMENTASI OBJECT RELATIONAL MAPPING PADA PETA DIGITAL SURABAYA BERBASIS
}

\author{
Arga Krismiyanto \\ Mahasiswa Jurusan Teknik Informatika, Fakultas Teknologi Informasi, \\ Institut Teknologi Adhi Tama Surabaya, Jl. Arief Rachman Hakim 100 Surabaya - 60117 \\ Email : argacrish@gmail.com
}

\begin{abstract}
Abstrak
Paradigma Object-Oriented Programming sangat banyak dipakai di kalangan pengembang perangkat lunak, di samping itu banyak perangkat lunak yang tidak bisa lepas dari penggunaan Database Relational. Keduanya sangat penting kegunaannya dalam pengembangan perangkat lunak. Akan tetapi, muncul ketidakcocokan paradigma antara keduanya yang sering disebut Object-Relational Mismatch, ketidakcocokan tersebut meliputi aspek Granularity, Subtypes, Identity, Association, dan Navigasi Data. Untuk mengatasi hal itu, dibutuhkan suatu metode pemetaan objek-objek yang mempresentasikan tabel-tabel entitas database, metode pemetaan tersebut adalah Object Relational Mapping (ORM). Pada aplikasi peta yang dibangun, metode pemetaan ini mempunyai peran untuk menangani pengolahan data informasi peta yang sangat banyak dan komplek. Di samping itu, peran metode pemetaan ini sangat penting terutama dalam hal kecepatan memproses data (running time). Hal ini dikarenakan metode pemetaan ini menyediakan model akses (query) yang tidak melibatkan secara langsung kepada database, melainkan pengaksesan terhadap objek-objek yang telah dipetakan. Model akses (query) yang disediakan oleh Object Relational Mapping (ORM) mempunyai perbandingan running time sebesar 1:1.51 lebih cepat, bila dibandingkan dengan sistem yang tidak menggunakan metode pemetaan ini, dengan batas pengujian jumlah record tabel sebanyak 50.000. Hal ini sangat menguntungkan untuk sebuah aplikasi mobile.
\end{abstract}

Kata kunci : Object-Oriented Programming(OOP), Object Relational Mapping (ORM), Object-Relational Mismatch. 


\begin{abstract}
Abstrac
Object-Oriented Programming Paradigm is very widely used among developers of software, in addition, a lot of software can not be separated from the use of Relational Databases. Both are very important usefulness in software development. However, emerging paradigm mismatch between them is often called Object-Relational Mismatch. It includes aspects of granularity, subtypes, Identity, Association, and Navigation Data. To overcome this, we need a method of mapping objects which presents tables database entity and it is called Object Relational Mapping (ORM). In the application building map, mapping method has a role to handle the data processing of map which is very much and complex. In addition, the role of mapping method is very important, especially in terms of data processing speed (running time). This is because the mapping method provides access model (query) that do not involve directly to the database but accessing to the objects that have been mapped. Access model (query) is provided by the Object Relational Mapping (ORM) has running time ratio of 1: 1:51 faster, if it is compared with systems that do not use this mapping method with the number of test limit records table as much as 50,000, It will have very beneficial for a mobile application.
\end{abstract}




\section{PENDAHULUAN}

Perkembangan

paradigma pemrograman berorientasi objek saat ini sangat pesat, banyak perangkat lunak saat ini yang dikembangkan dengan paradigma berorientasi objek. Namun, muncul permasalahan ketidaksesuaian antara basisdata relasional dengan pengembangan aplikasi yang menggunakan konsep berorientasi objek yang sering disebut Object-Relational

Mismatch, ketidaksesuaian tersebut meliputi aspek Granularity, Subtypes, Identity, Association, dan Navigasi Data.

Oleh karena ketidaksesuaian tersebut, maka diimplementasikan konsep Object Relational Mapping (ORM). Setiap objek yang akan memetakan menjadi tabel-tabel pada basis data relasional dibungkus oleh suatu interface dengan menerapkan konsep design pattern. Hal tersebut bertujuan untuk memudahkan integrasi dengan lapisan aplikasi (controller) mengakses data tersebut.

Implementasi Object Relational Mapping (ORM) ini dibagi menjadi beberapa tahapan, yaitu pemetaan Data Transfer Object dengan menghilangkan paradigma ketidaksesuaian antara basis data relasional dengan pemrograman berorientasi objek, membuat fungsi-fungsi akses data dengan mengimplementasikan Data Access Object (DAO) pattern, menyederhanakan fungsi akses data dengan memanfaatken konsep design pattern, membuat skema basis data, dan menyatukan lapisan persistensi dan lapisan aplikasi.
Pada aplikasi peta digital offline, implementasi Object Relational Mapping (ORM) sangat dibutuhkan untuk pemetaan

objek-objek relasional dari informasi peta yang diperoleh, disamping itu sebagai model transaksi yang menyediakan layanan pengolahan data peta.

Berdasarkan latar belakang diatas dapat dirumuskan permasalahan yaitu :

1 Bagaimana mengimplementasikan metode Object Relational Mapping untuk memetakan informasi Peta Openstreetmap ke dalam Object Relational?

2 Bagaimana mengimplementasikan teknologi Object Relational Mapping sebagai penyedia layanan pengolah informasi pada Aplikasi Peta Digital Offline Android?

Dengan melihat permasalahan diatas, terdapat beberapa batasan masalah, yaitu sebagai berikut :

1 Menggunakan metode Object Relational Mapping.

2 Sumber data yaitu data $\mathrm{xml}$ Openstreetmap dan inputan dari user.

3 Menggunakan framework GreenDao.

4 Aplikasi Peta Digital bersifat offline dan berjalan di platform Android.

5 Database yang digunakan adalah SQLite database.

6 Minimal target android versi 2.30 (Gingerbread).

\section{TINJAUAN PUSTAKA}

Object-Relational Mismatch adalah ketidaksesuaian antara basis data yang menggunakan konsep relasional dengan 
pengembangan aplikasi yang menggunakan konsep berorientasi objek. (Bauer, C. \& Raja, G. 2007) memperkenalkan daftar objek / masalah ketidaksesuaian relasional:

\section{Granularity}

Pemecahan entity pada atribut-atribut yang lebih kompleks. Misalnya Class Person mempunyai atribut address dengan tipe data Address. Sedangkan pada basis data relasional tidak memungkinkan pada table Person ada kolom address dengan tipe data address, yang mungkin dilakukan adalah memecah address menjadi street_address, city_addres.

2. Subtypes

Pembeda antara superclass dan subclass. Pada pemrograman berbasis objek dikenal istilah inheritance (pewarisan) dari class parent kepada class child. Sedangkan pada basis data relasional tidak dikenal proses pewarisan antar tabel.

3. Identity

Terdapat perbedaan fungsi antara lambang sama dengan (=) dan method equals() pada objek tetapi merujuk nilai yang sama pada primary key basis data relasional.

4. Association

Hubungan dua entitas pada objek dikenal dengan references sedangkan pada relasional dikenal dengan foreign key. Asosiasi antar entity terdiri dari: one-to-one, one-to-many, dan manyto-many.

5. Data Navigation

Proses pencarian pada basis data menggunakan join table sedangkan pada objek memanggil suatu method getter. Navigasi dibagi dua macam berdasarkan arahnya, antara lain: directional dan bidirectional. (Bauer dan King 2007).

Dengan adanya ketidaksesuaian tersebut, maka muncul metode pemetaan Object Relational Mapping, yaitu pemetaan dari model relasional ke model objek, atau sebaliknya, dimana tabel database dipetakan ke dalam kelas-kelas, atau sebaliknya kelas-kelas dipetakan ke dalam bentuk database relasional. (Ambler, Scott W. 2007).

Dalam Object Relational Mapping (ORM) terdapat dua jenis pemetaan, yaitu forward mapping dan reverse mapping.

1. Forward Mapping akan mengambil objek yang sudah dibuat dalam class dan kemudian membuat skema database dari objek tersebut. Berikut adalah gambaran dari pemetaan jenis Forward Mapping :

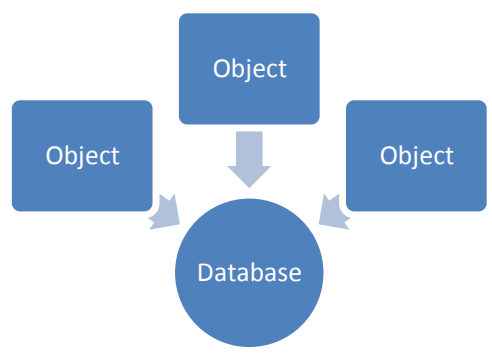

Gambar 1. Pemetaan forward mapping

2. Sedangkan Reverse Mapping akan mengambil database yang sudah ada dan akan menciptakan objek-objek dari tabel-tabel yang sudah ada di dalam database. Berikut gambaran jenis pemetaan Reverse Mapping: 


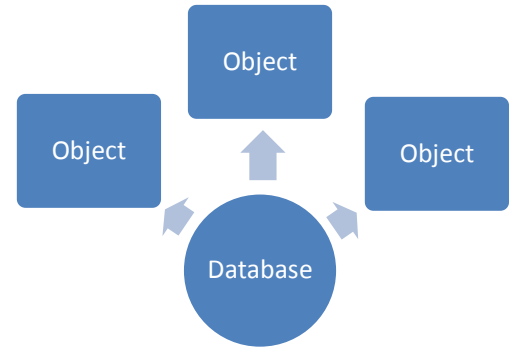

\section{Gambar 2. Pemetaan reverse mapping}

GreenDAO adalah sebuah proyek open source untuk membantu pengembang Android bekerja dengan data stored di SQLite. SQLite adalah salah satu database relasional yang mengagumkan dilingkungan Android. Namun, untuk mengembangkan itu memerlukan banyak hal yang harus dilakukan dengan kata lain dibutuhkan tools tambahan untuk mendukung kinerjanya. Menggunakan perintah Structured Query Language (SQL) dan parsing hasil query adalah pekerjaan cukup membosankan. GreenDAO akan sangat membantu dan menggantikan pekerjaan tersebut yaitu mapping object untuk tabel database. Dengan cara ini memungkinkan untuk dapat menyimpan, memperbarui, menghapus, dan permintaan untuk objek Java menggunakan API berorientasi objek sederhana. Tujuan desain utama GreenDAO ini

1. Kinerja maksimum

2. API mudah digunakan

3. Sangat dioptimalkan untuk Android

4. Pemakaian memori minimal

5. Ukuran library kecil

Berikut gambaran umum pembuatan entitas dan domain project dari GreenDAO

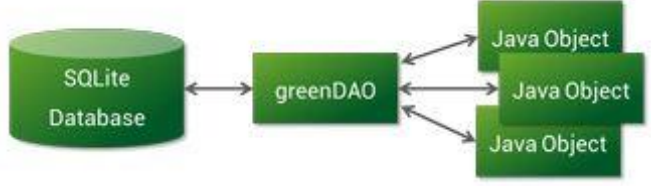

Gambar 3. Fungsionalitas GreenDAO

GreenDAO juga menawarkan fitur auto-generate objek, yang di-generate secara otomatis sesuai dengan model skema entitas yang dibentuk. Berikut gambaran umum fitur auto-generate objek

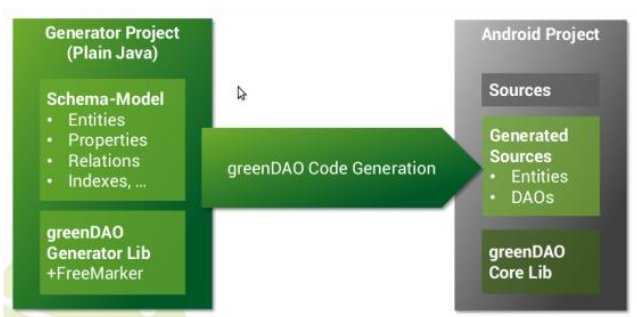

Gambar 4. Fitur auto-generate objek GrennDAO

Berikut adalah kelas-kelas inti dari interface penting hasil dari generator GreenDAO :

1. DaoMaster

Fungsi utamanya adalah memegang objek database (SQLiteDatabase) dan mengelola kelas DAO (bukan objek) untuk skema tertentu. Kelas ini memiliki metode static untuk membuat atau menghapus tabel.

Terdapat kelas helper yang merupakan implementasi dari SQLiteOpenHelper yang membuat skema dalam database SQLite .

2. DaoSession

Mengelola semua objek Data Access Object (DAO) yang tersedia untuk skema tertentu, untuk memperolehnya menggunakan salah satu metode getter. DaoSession juga menyediakan beberapa generic persistence methods seperti insert, load, update, refresh 
dan delete untuk entitas. Objek DaoSession juga melacak lingkup identitas.

3. DAOs

Data Access Object ( DAOs ) yang bersifat persist dan digunakan untuk query entitas. Untuk setiap entitas yang dihasilkan GreenDAO mempunyai DAO. yang memiliki metode persist lebih banyak dari DaoSession, misalnya : Count, LoadAll, dan insertInTx.

4. Entity

Entity adalah object Persistable. Objek-objek ini yang mewakili baris database menggunakan properti Java standar (seperti POJO atau JavaBean).

Openstreetmap adalah proyek yang bertujuan untuk membuat dan menyediakan data geografi seperti peta jalan secara gratis. Openstreetmap merepresentasikan informasi geografi tersebut dalam format file xml dengan empat element yang terdiri atas Node, Relation, Way dan Tag. Penjelasan dari masing-masing elemen:

1. Node

Elemen ini mendefinisikan persimpangan atau lokasi. Node memiliki atribut utama id, lon (longitude), dan lat (latitude).

2. Way

Elemen ini mendefinisikan jalan. Way hanya memiliki satu atribut utama yaitu id. Way terdiri atas satu atau lebih segment.

3. Relation

Elemen ini mendefinisikan relasi antara Node dan Way.

4. Tag

Elemen ini dapat mendefinisikan nama atau kategori dari lokasi. Elemen ini juga dapat mendefinisikan nama jalan, kategori jalan, dan arah dari jalan tersebut. Elemen ini dapat menjadi anak dari elemen Node, segment, dan Way.

\section{METODE PENELITIAN}

Metode Object Relational Mapping ini menggunakan dua pendekatan pemodelan, pendekatan pemetaan table-per-concreteclass dan pendekatan model pemetaan forward mapping. Pemetaan table-perconcrete-class yaitu pemetaan objek diperoleh dari entitas konkrit yang diperoleh,dalam artian setiap entity dipetakan menjadi satu objek, sedangkan pemodelan forward mapping adalah pembuatan database dari objek yang sudah dibuat, dengan kata lain membentuk terlebih dahulu objek-objek yang dibutuhkan.

$$
\text { Langkah pertama yaitu }
$$
mengidentifikasi konkrit kelas dari sumber data Openstreetmap, pada tahap ini juga ditentukan objek-objek yang akan dibentuk dari hasil identifikasi konkrit kelas yang mungkin bisa dibentuk dan dijadikan satu objek. Berikut hasil identifikasi konkrit kelas :

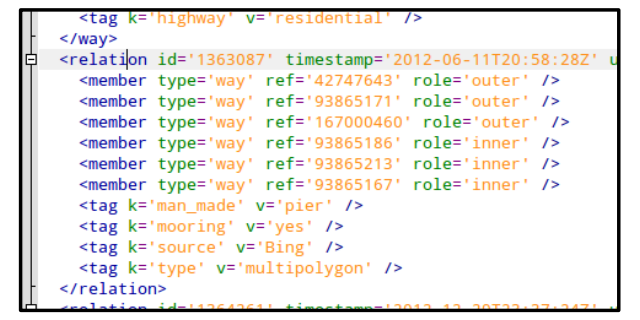

\section{Gambar 5. Isi dari file openstreetmap}

$(x m l)$

Dari data openstreetmap diatas, dapat kita peroleh hasil identifikasi, berikut konkrit kelas yang terbentuk. 


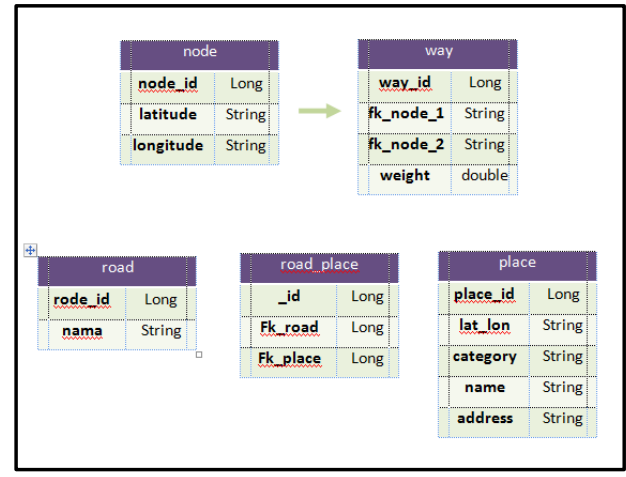

Gambar 6. Hasil identifikasi konkrit kelas

Dari tabel tersebut, pada entitas way, penentuan atribut " $f k_{-}$node_l" dan " $f k \_n o d e \_l$ " ditentukan berdasarkan teori directed graph, yaitu satu way mempunyai beberapa node didalamnya, oleh karena di dalam way ada node lebih dari satu maka kardinalitas dari way ke node adalah many to one, dengan attribute dari entitas way " $f k \_n o d e \_l "$ dan " $f k \_n o d e \_2 "$ adalah foreign key dari entitas node.

Langkah kedua yaitu memetakan objek dari identifikasi entitas. GreenDAO menyediakan generate skema database dari objek yang dibuat, Berikut struktur skema objek dari GreenDAO :

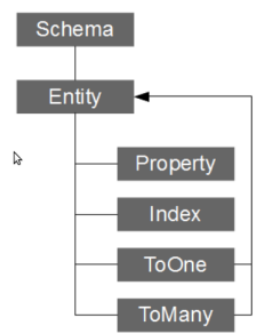

Gambar 7. Struktur Skema Greendao

Berikut potongan source code untuk pemetaan objek dengan :

\section{...}

Entity node = schema.addEntity("Node"); node.setTableName("NODE");

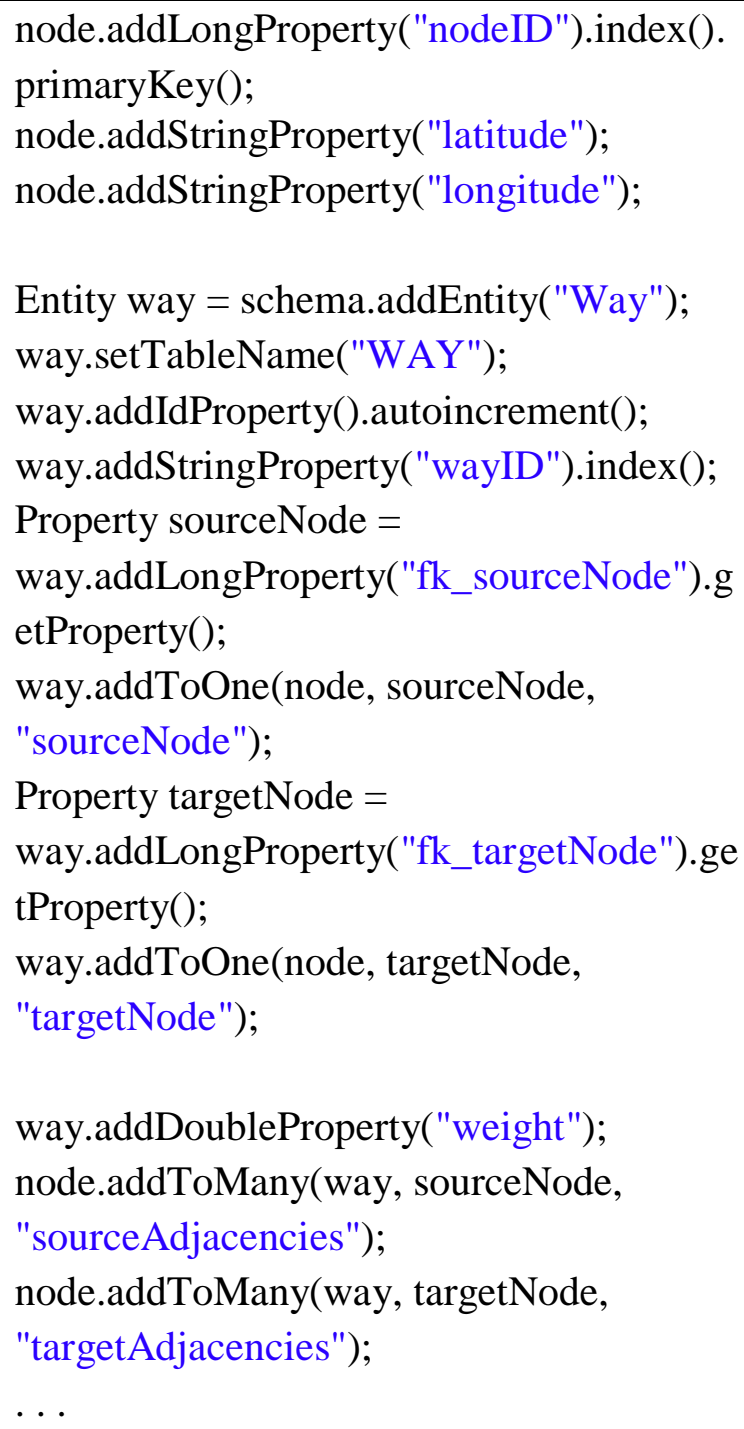

Dari pendefinisian skema objek diatas, diperoleh beberapa kelas sesuai dengan skema yang telah didefinisikan. Berikut kelas diagram yang menunjukkan hasil dari pendefinisian skema diatas : 


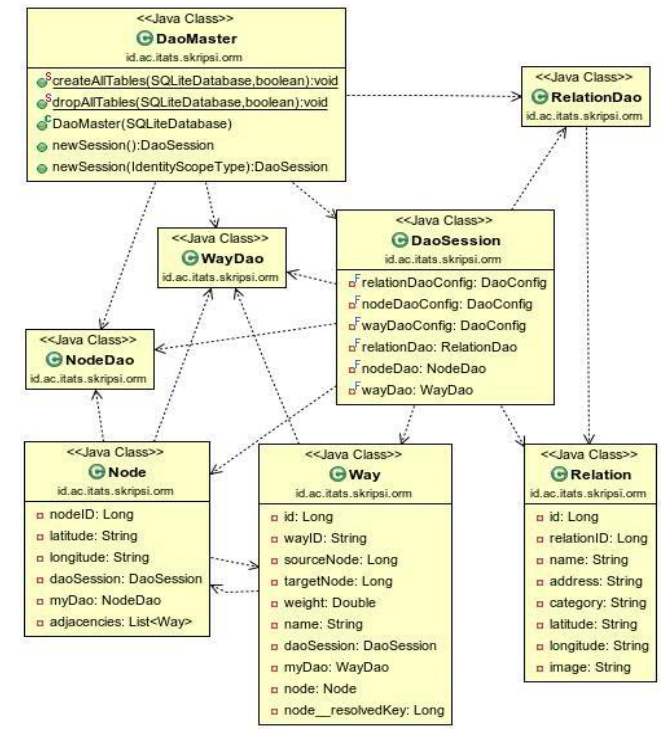

Gambar 8. Kelas diagram hasil pendefinisian skema

Langkah berikutnya adalah pembuatan database dari objek-objek yang telah dibuat. Berikut potongan source code pembuatan database-nya:

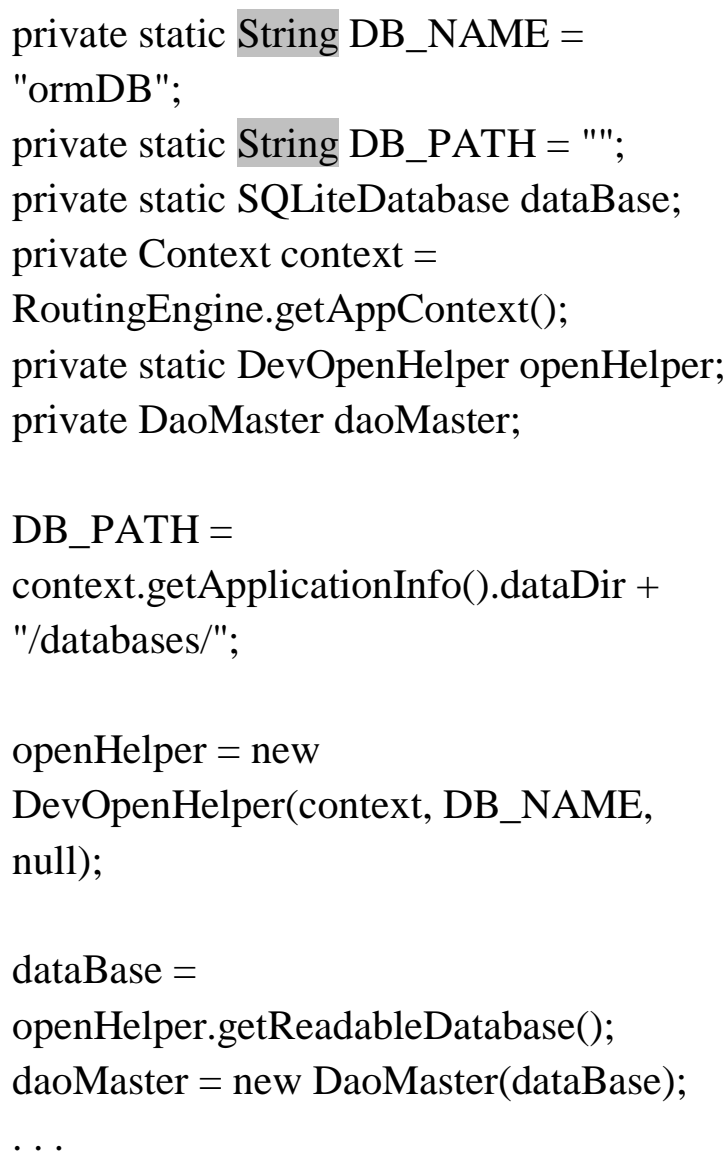

Objek-objek yang telah dibuat adalah merupakan representasi dari tabel-tabel yang ada di database. Berikut gambaran dan selesai :

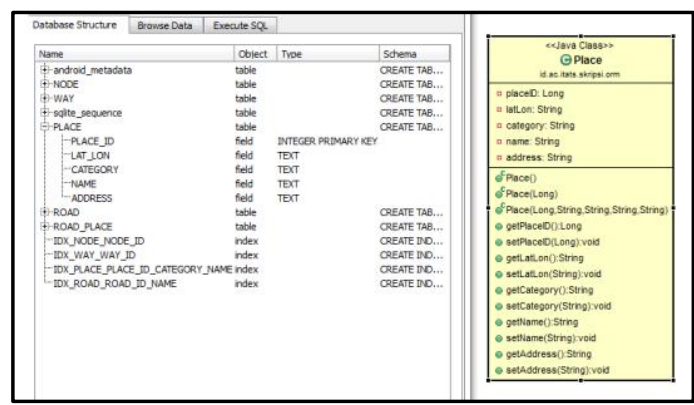

\section{Gambar 9. Gambaran objek dan database}

Setelah perancangan objek dan database, langkah berikutnya adalah parsing data $x m l$ dari Openstreetmap sebagai master data awal dari aplikasi ini, dan juga proses input data ke database yang telah dibuat. Berikut hasil parsing dan input data ke dalam database :

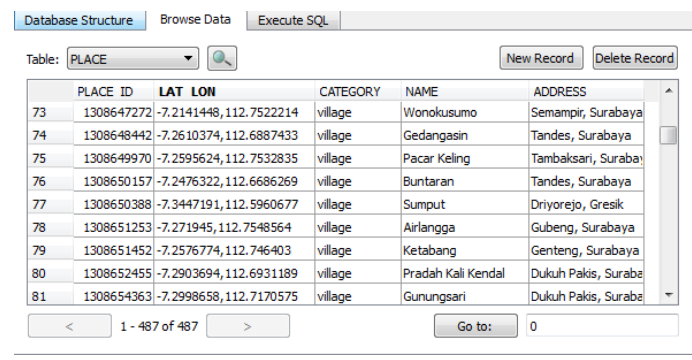

Gambar 10. Isi database hasil dari inputan awal

Perancangan user interface dilakukan untuk memudahkan user berinteraksi dengan sistem. Berikut diagram use case : 


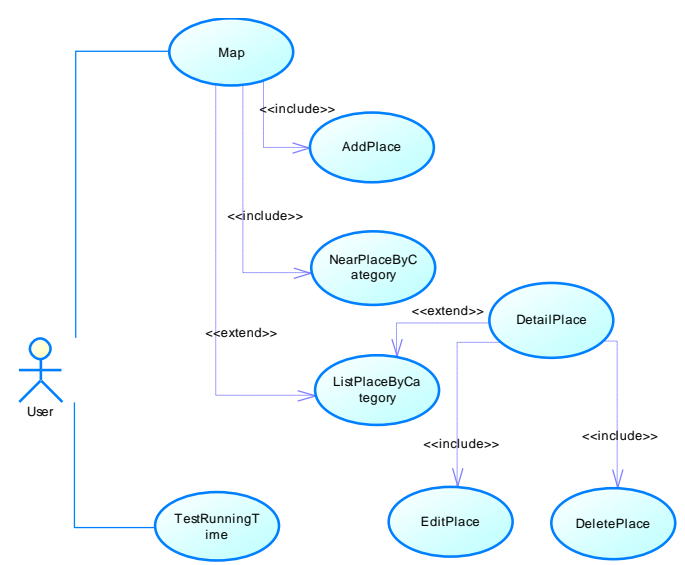

Gambar 11. Use Case Diagram Sistem HASIL

Aplikasi yang dibagun ini digunakan untuk memudahkan user memanipulasi data khususnya untuk layanan CRUD (Create, Read, Update, dan Delete) data Peta Digital Surabaya. Berikut adalah tampilah awal dari aplikasi ini.

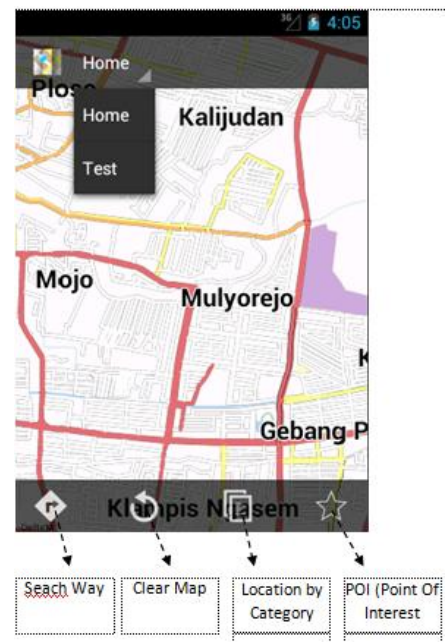

\section{Gambar 12. Tampilan utama aplikasi}

Tampilan utama aplikasi mempunyai fitur utama yaitu menu pencarian POI (Point Of Interest) atau lokasi menarik di surabaya sesuai kategori yang dipilih, disamping itu user bisa menambah lokasi yang diinginkan dan menyimpannya. Berikut adalah tampilan Point Of Interest.

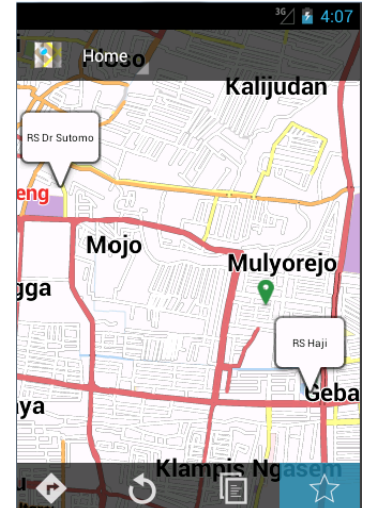

Gambar 13. Tampilan Point Of Interest

Menu Location By Category digunakan untuk mencari nama lokasi sesuai dengan kategori yang dipilih, pada menu ini user disediakan interface untuk men-edit atau menghapus data peta. Berikut adalah tampilan halaman Location by Category.

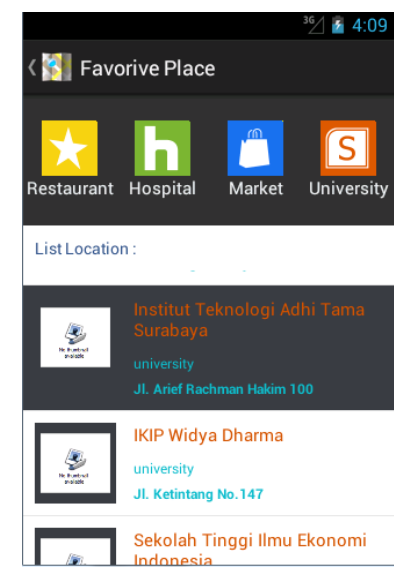

\section{Gambar 14. Tampilan Location by Category}

Pengujian digunakan untuk membandingkan hasil kinerja sistem dengan menggunakan metode Object Relational Mapping (ORM) dan hasil kinerja sistem tidak menggunakan metode ini. Pengujian aplikasi dilakukan di dua media, yaitu pengujian pada Emulator dan pada Handphone.

1. Spesifikasi Emulator 
Android versi 4.2.2 - API Level 17, RAM $512 \mathrm{Mb}$, VM Heap 128, SD Card $200 \mathrm{Mb}$, CPU ARM armeabiv7a.

\section{Spesifikasi Handphone}

Android versi 4.1.1 - API Level 16, RAM up to $512 \mathrm{Mb}$, CPU snapdragon $1 \mathrm{Ghz}, \mathrm{SD}$ card.

Parameter pengujian sistem yang dipakai adalah tabel Road_Place yang mempunyai 99.666 record dan terdiri dari 3 kolom yaitu id (long integer), fk_road (long integer), fk_place (long integer). Model query pengujian yang dipakai menggunakan query object yang dimiliki oleh framework Object Relational Mapping (ORM) yaitu GreenDAO dan model query menggunakan sintak Structured Query Language (SQL) Cursor. Dalam pengujian ini keduanya akan dibandingkan hasil running time dalam satuan second. Berikut hasil pengujian di Emulator.

Tabel 1. Hasil pengujian di Emulator

\begin{tabular}{|l|c|c|}
\hline \multicolumn{1}{|c|}{ Limit } & \multicolumn{2}{|c|}{$\begin{array}{c}\text { Running Time Read Table } \\
\text { (second) }\end{array}$} \\
\hline Record & $\begin{array}{c}\text { ORM } \\
\text { (GreenDao) }\end{array}$ & SQL Cursor \\
\hline 1000 & 0.17575671 & 0.12699564 \\
\hline 5000 & 0.655504 & 0.91795516 \\
\hline 10000 & 1.4218229 & 1.772055 \\
\hline 15000 & 1.9257964 & 2.772172 \\
\hline 20000 & 2.9430258 & 4.3937783 \\
\hline 25000 & 4.2848606 & 6.1339526 \\
\hline 30000 & 6.6333237 & 8.869842 \\
\hline 35000 & 7.9629455 & 12.203024 \\
\hline 40000 & 10.338376 & 15.490026 \\
\hline 45000 & 11.8720665 & 19.030912 \\
\hline 50000 & 15.182456 & 22.292103 \\
\hline & & \\
\hline
\end{tabular}

\begin{tabular}{|l|c|c|}
\hline Average & $\begin{array}{c}5.76326673 \\
7\end{array}$ & $\begin{array}{c}8.54571051 \\
8\end{array}$ \\
\hline $\begin{array}{l}\text { Perbandinga } \\
\mathrm{n}\end{array}$ & 1 & 1.48 \\
\hline
\end{tabular}

Tabel 2. Hasil Pengujian di Handphone

\begin{tabular}{|l|c|c|}
\hline \multicolumn{1}{|c|}{ Limit } & $\begin{array}{c}\text { Running Time Read Table } \\
\text { (second) }\end{array}$ \\
\hline \multicolumn{1}{|c|}{ Record } & $\begin{array}{c}\text { ORM } \\
\text { (GreenDao) }\end{array}$ & SQL Cursor \\
\hline 1000 & $\begin{array}{c}0.06354333 \\
5\end{array}$ & 0.05637333 \\
\hline 5000 & 0.1397767 & 0.17734 \\
\hline 10000 & 0.24597499 & 0.33923334 \\
\hline 15000 & 0.350615 & 0.50091004 \\
\hline 20000 & 0.63613 & 0.718085 \\
\hline 25000 & 0.6579084 & 0.9721383 \\
\hline 30000 & 0.93967336 & 1.4790934 \\
\hline 35000 & 1.066066 & 1.7843167 \\
\hline 40000 & 1.521885 & 2.16342 \\
\hline 45000 & 1.6020634 & 2.7548666 \\
\hline 50000 & 2.0514967 & 3.0172317 \\
\hline & & \\
\hline Average & 0.84319389 & 1.26936440 \\
& 9 & 1 \\
\hline $\begin{array}{l}\text { Perbandinga } \\
\mathrm{n}\end{array}$ & 1 & 1.51 \\
\hline
\end{tabular}

Pada hasil pengujian sistem dapat diperoleh rata-rata dan perbandingan running time yang menunjukkan bahwa sistem yang menggunakan metode Object Relational Mapping (ORM) lebih cepat dengan perbandingan 1 : 1.48 pada Emulator dan 1 : 1.51 pada Handphone.

Proses query yang dilakukan keduanya sama-sama mempunyai hasil (return) berupa List object, dan batas running time yang dihitung belum sampai hasil (return) ditampilkan, bisa dikatakan proses yang dihitung hanya sampai membentuk List object yang berisi hasil query.

Model query yang dimiliki Object Relational Mapping (GreenDAO) lebih cepat dikarenakan pada saat object-object 
ini di instansi, secara otomatis nilai (values) object tersebut sama dengan tabel yang direpresentasikan, sehingga pada saat query dilakukan, nilai pada object itulah yang dikembalikan (return). Berbeda dengan model query dengan menggunakan SQL Cursor yang secara langsung merequest data tabel yang ada di database.

\section{KESIMPULAN}

Pada hasil pengujian yang dilakukan, kesimpulan utama implementasi metode Object Relational Mapping pada aplikasi ini adalah running time proses lebih cepat dibandingkan tidak menggunakan metode ini. Kesimpulan secara keseluruhan adalah sebagai berikut :

1. Proses running time pada aplikasi lebih cepat, dari hasil pengujian pada emulator android, perbandingan antara sistem yang menggunakan Object Relational Mapping dengan sistem yang tidak memakai metode ini adalah 1:1.48 dalam satuan second.

2. Pengujian yang kedua yaitu pada handphone, proses running time aplikasi juga lebih cepat dengan perbandingan 1:1.51 dalam satuan second.

3. Kelemahan menggunakan aplikasi ini adalah pada saat awal aplikasi dijalankan, running time sedikit lambat dikarenakan sistem melakukan instansi semua object yang dibutuhkan oleh sistem.

\section{DAFTAR PUSTAKA}

Scott W. Ambler. 2000. Mapping Objects to Relational Databases: $\mathrm{O} / \mathrm{R}$ mapping in detail.

Chris J Harrison, Omar M Sallabi, Stephen E Eldridge. 2002. A persistent programming environment for teaching object-oriented concepts, Computer Software and Applications Conference.

Bauer, C. \& King, G. 2007. Java Persistence with Hibernate. Manning Publication Co.

Sanjaya, David Adi. 2008. Implementasi Model View Controller dan Object Relational Mapping pada Content Management System Sistem Informasi Keuangan. AITI Jurnal Teknologi Informasi, 6(1):30-44

Barnes, Jeffrey M. 2007. Object-Relational Mapping as a Persistence Mechanism for Object-Oriented Applications. Minnesota : the Department of Mathematics and Computer Science at Macalester College in Saint Paul.

Simitci, Aysun. 2008. Object-Relational Mapping in Database Design. Bothell : The Master of Science in Computing \& Software Systems University of Washington.

PRABHU, P. 2013. MAPPING OBJECTS TO RELATIONAL DATABASE FOR OBJECT PERSISTENCE. Karaikudi : Assistant Professor in Information Technology Directorate of Distance Education Alagappa University. 
